\title{
A 3-D model to analyze environmental effects of dredging operations - application to the Port of Marin, Spain
}

\author{
J. García Alba, A. G. Gómez, R. O. Tinoco López, M. L. Sámano Celorio, A. García Gómez, and J. A. Juanes \\ Environmental Hydraulics Institute "IH Cantabria", Universidad de Cantabria, Santander, Spain \\ Correspondence to: J. García Alba (garciajav@unican.es)
}

Received: 14 October 2013 - Revised: 13 December 2013 - Accepted: 16 December 2013 - Published: 1 April 2014

\begin{abstract}
Historically, the study of dredging processes has depended on physical laboratory tests. The IH-Dredge model has been developed to simulate these processes numerically. It simulates the evolution of the seabed, sediment and toxic substances involved in dredging operations. The model has been calibrated and validated with experimental data, and it has been applied in a dredging operation in the Port of Marin, Spain.
\end{abstract}

\section{Introduction}

Dredging processes effects have been largely tested through physical experiments (Vlasbom, 2005). However, the development of mathematical models allows predicting those effects without the need of expensive physical models. Nowadays, there are widely trusted sediment transport models that can estimate the suspended solids and the dredging operations as a final configuration with its effect in the water column (Song and Haidvogel, 1994; Jacobsen and Rasmussen, 1997; Deltares, 1999; Hervouet and Bates, 2000; Bai et al., 2003).

\section{IH-Dredge model description}

The finite-difference model presented herein (IH-Dredge) is a three-dimensional Eulerian code which solves the advection-diffusion equation (Eq. 1) to simulate sediment transport (Eq. 2) and evolution of toxic substances, in both dissolved and particulate fractions in water and sediment.

$$
\begin{aligned}
& \frac{\partial \phi}{\partial t}+\frac{\partial u \phi}{\partial x}+ \frac{\partial v \phi}{\partial y}+\frac{\partial w \phi}{\partial z}=\frac{\partial}{\partial x}\left(D_{x} \frac{\partial \phi}{\partial x}\right)+ \\
&+\frac{\partial}{\partial y}\left(D_{y} \frac{\partial \phi}{\partial y}\right)+\frac{\partial}{\partial z}\left(D_{z} \frac{\partial \phi}{\partial z}\right)+R \\
& \frac{\partial c_{\mathrm{s}}}{\partial t}+\frac{\partial u c_{\mathrm{s}}}{\partial x}+\frac{\partial v c_{\mathrm{s}}}{\partial y}+\frac{\partial\left(w-w_{\mathrm{s}}\right) c_{\mathrm{s}}}{\partial z}=\frac{\partial}{\partial x}\left(\varepsilon_{\mathrm{s}, x} \frac{\partial c_{\mathrm{s}}}{\partial x}\right)+ \\
&+\frac{\partial}{\partial y}\left(\varepsilon_{\mathrm{s}, y} \frac{\partial c_{\mathrm{s}}}{\partial y}\right)+\frac{\partial}{\partial z}\left(\varepsilon_{\mathrm{s}, z} \frac{\partial c_{\mathrm{s}}}{\partial z}\right)
\end{aligned}
$$

where $\phi$ is the pollutant concentration, $D_{x}, D_{y}, D_{z}$ are the turbulent diffusion coefficients, $R$ is the reaction term, $c_{\mathrm{s}}$ is the mass concentration of sediment fraction, $w_{\mathrm{s}}$ is the settling velocity of sediment fraction and $\varepsilon_{\mathrm{s}, x}, \varepsilon_{\mathrm{s}, y}, \varepsilon_{\mathrm{s}, z}$ are the eddy diffusivities of sediment fraction. The $\sigma$-coordinate is used for the vertical discretization.

Sedimentation is obtained as a function of the critical shear stress for deposition $\tau_{\mathrm{d}}$, the critical shear stress for erosion $\tau_{\mathrm{e}}$ and the bed shear stress $\tau_{\mathrm{b}}$. The model allows using different formulations for computing critical shear stress for deposition: Wu and Falconer (2000), Alvera-Azcárate et al. (2003), Cancino and Neves (1999), Huang et al. (2006), Wu et al. (2005), Zheng et al. (2004), Vidal et al. (2005), or a userdefined value. The critical shear stress for erosion is calculated by either Cancino and Neves (1999), Huang et al. (2006), Vidal et al. (2005), or a user-defined value. Finally, the bed shear stress can be calculated by Cappucci et al. (2004), Alvera-Azcárate et al. (2003), Lumborg and Pejrup (2005), or a user defined value.

The model allows the interaction of suspended particles with the pollutants present not only in the water column, but also in the seabed. Adsorption-desorption, biodegradation, 


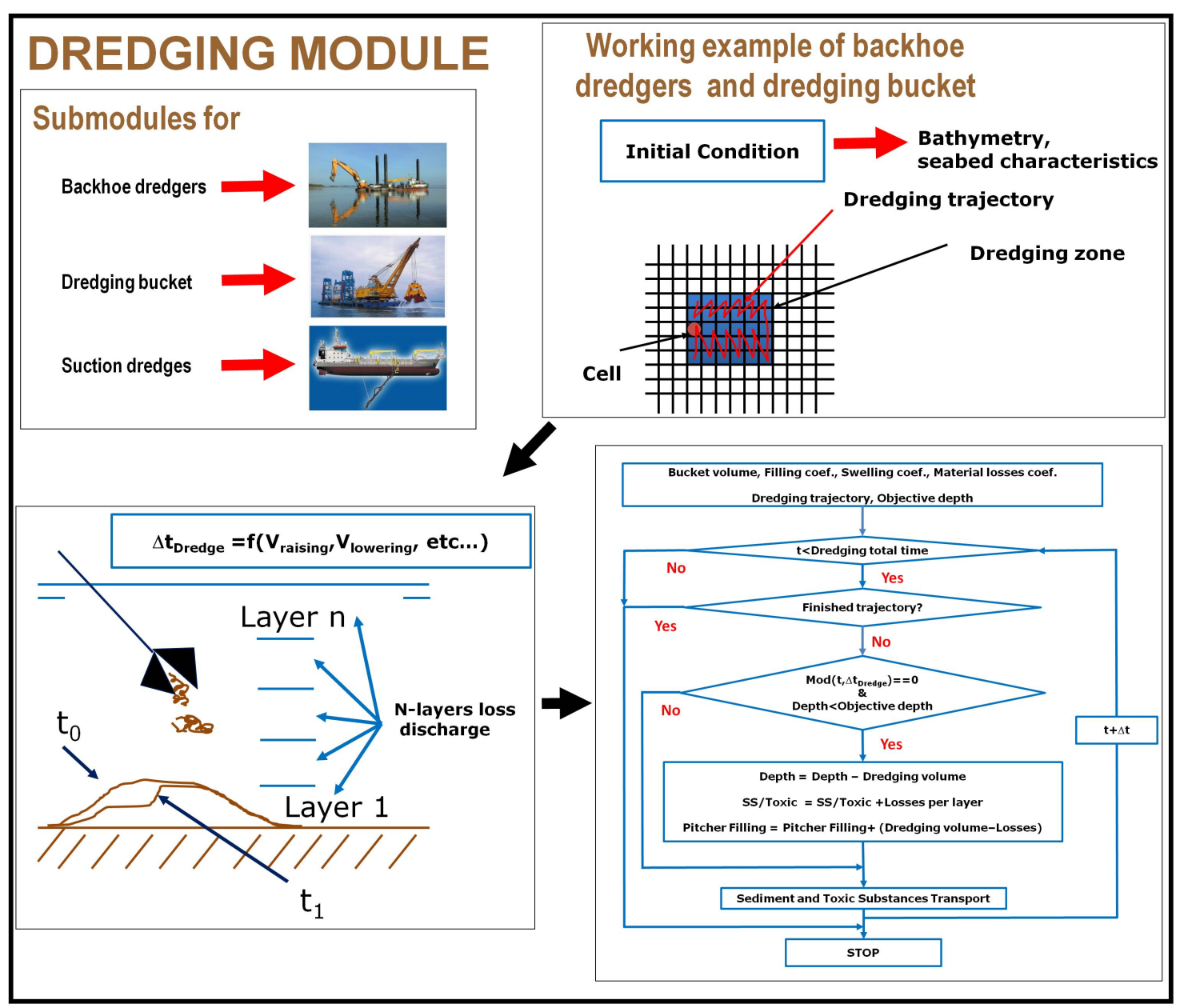

Fig. 1. Example of IH-Dredge working model.

volatilization, photolysis, hydrolysis and water-sediment diffusion processes are taken into consideration to simulate the pollutants behaviour. Moreover, the model considers the removal of the seabed material effect on the pollutants concentration in the water column (de Boer, 2007).

Unlike final configuration models, IH-Dredge simulates at each time step the effects of different dredging techniques such as: suction dredges, backhoe dredgers and dredging buckets. The backhoe and bucket dredging simulation algorithms are based on the net extraction in a dredge cycle considering material losses and specific filling and swelling coefficients (associated with each one of the involved cells in the lifting process simulation). Suction dredging algorithms allow considering, in real time, the pitcher filling and the overflow losses while traveling through the dredging area. An example of the IH-Dredge working model scheme is shown in Fig. 1.

\section{Calibration and validation with experimental data}

The model has been calibrated and validated with laboratory experiments at the IHLab-Hydro at the IH Cantabria. Material loss effects of dredging bucket rising has been simulated in a stagnant medium and with a current of $0.1 \mathrm{~m} \mathrm{~s}^{-1}$. The rising effect of the dredge with its associated losses has been studied with the rise of a $10^{-3} \mathrm{~m}^{3}$ cylindrical plastic container, a duquesa pot, using an overhead crane. Dredger losses were simulated by sand poured through holes made in the base of the duquesa pot. The crane rised the pot at a constant speed of $1.25 \mathrm{~cm} \mathrm{~s}^{-1}$. The water level during the test was maintained at $0.6 \mathrm{~m}$. The loss of material as the duquesa pot raised was measured as $1.4545 \times 10^{-5} \mathrm{~m}^{3} \mathrm{~s}^{-1}$. Five acoustic doppler velocimeters (ADV) were placed vertically at $5,13.5,21,26.5$ and $32.5 \mathrm{~cm}$ from the bottom to measure the velocity profile during experimental tests. An optical backscatter sensor (OBS) was used to record the concentration of suspended solids at $5 \mathrm{~cm}$ above the bottom. The 

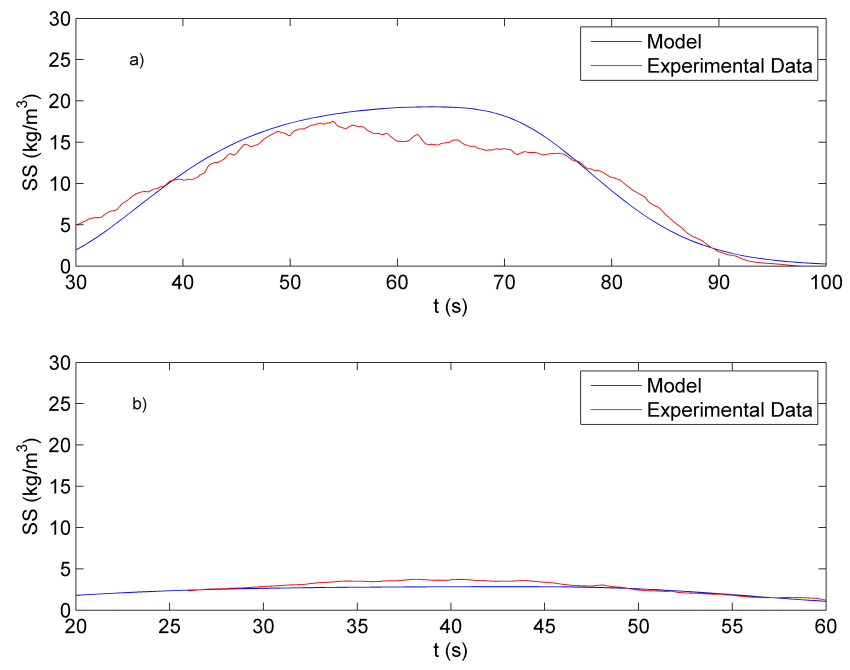

Fig. 2. (a) Comparison of model results with the recorded data in the trial without current. (b) Comparison of model results with the recorded data in the experiment with the presence of $0.1 \mathrm{~m} \mathrm{~s}^{-1}$ currents.

OBS was previously calibrated with the same sand used for the experiment (siliceous arid with $D_{50}$ of $0.4 \mathrm{~mm}$ ).

Calibration of the IH-Dredge model was carried out through numerical reproduction of the laboratory experiments. A domain of $81 \times 40$ square regular cells of $0.05 \mathrm{~m}$ with a constant depth of $0.6 \mathrm{~m}$ was considered. Vertical direction was discretized into $10 \sigma$-layers.

The calibration was made comparing the sediment concentration obtained by the model with the one recorded by the OBS. We obtained a value of $10^{-6} \mathrm{~m}^{2} \mathrm{~s}^{-1}$ for the horizontal eddy diffusivity of the sediment fraction, with a CE (Nash and Sutfliffe, 1970) of 0.65 (good), a correlation coefficient of 0.85 and mean square error of $2.3 \mathrm{mg} \mathrm{L}^{-1}$ (Fig. 2a).

The model validation was conducted with the obtained OBS data with a uniform current of $0.1 \mathrm{~m} \mathrm{~s}^{-1}$, as measured with the array of ADVs. Field currents were introduced in the model as a constant and homogeneous value of $0.1 \mathrm{~m} \mathrm{~s}^{-1}$. During the validation process we obtained a skill CE of 0.91 (excellent), a correlation coefficient of 0.89 and mean square error of $0.41 \mathrm{mgL}^{-1}$ (Fig. 2b).

\section{IH-Dredge application to the Port of Marin}

IH-Dredge has been applied to a dredging operation conducted in the Port of Marin, in an area of $18750 \mathrm{~m}^{2}$. Marin is a Spanish town located in the province of Pontevedra, in the autonomous community of Galicia, located on the southern shore of the Ria de Pontevedra. DELFT3D model was applied in the study area to derive the hydrodynamics forcing conditions (Three dimensional currents, salinity and temperature fields). Modeled free surface elevations were compared to the Port of Marin tidal gauge data. Modeled salin- ity and velocity profiles were verified with the measurements obtained during a field survey performed on 26 April 2012.

The following dredging characteristics have been used in the simulation:

- Dredging process with a dredging bucket of $4 \mathrm{~m}^{3}$ capacity.

- Objective depth in dredging zone of $12 \mathrm{~m}$.

- Dredging sediment density of $2650 \mathrm{~kg} \mathrm{~m}^{-3}$.

- Critical shear stress for erosion of $0.6531 \mathrm{~kg} \mathrm{~m}^{-1} \mathrm{~s}^{-2}$.

- Critical shear stress for deposition of $0.5477 \mathrm{~kg} \mathrm{~m}^{-1} \mathrm{~s}^{-2}$

- Rising and download velocity of bucket are equal to $1 \mathrm{~ms}^{-1}$.

- The time of digging was $10 \mathrm{~s}$ for each dredging event.

- Operation time of dredge turning to barge was $6 \mathrm{~s}$.

- Filling, swelling and material losses coefficients were $0.6,0.7$ and 1.15 , respectively.

Cadmium presence in the sea bottom has been considered with the following characteristics:

- Bottom concentration of $1.27 \mathrm{ppm}$.

- Henry constant: $3.1 \times 10^{-2} \mathrm{~atm} \mathrm{~m}^{3} \mathrm{~mol}^{-1}$.

- Partition coefficient $K_{\mathrm{p}}: 5.01 \times 10^{4}$.

- Water-octano coefficient $K_{\mathrm{OW}}$, hydrolysis coefficient $K_{\text {hid }}$, photolysis coefficient $K_{\text {fot }}$ and biodegradation coefficient $K_{\text {bio }}$ equal to zero.

A mesh of $122 \times 102$ square regular cells of $25 \mathrm{~m}$ and a vertical discretization with $5 \sigma$-layers was used. A null concentration of suspended solids and cadmium in the water column was considered as initial condition. Open boundaries were modelled with a Dirichlet condition for suspended solids and cadmium concentration with null value. Suspended solids concentration (Fig. 3a) and cadmium concentration (Fig. 3b) on the $5 \sigma$-layers and depth evolution (Fig. 3c) during the dredging process were obtained.

The concentration of suspended solids and cadmium in each of the 5 vertical layers is shown in Fig. $3 a$ and b. Material looses of dredging process have a larger effect on the surface layer than on the bottom layer due to advection processes, which in this case (mixing dominated to velocity profile) are more important than dispersion processes. Dredging bucket simulation results show that the dredging process would need continuous work for $195 \mathrm{~h}$ to achieve the objective depth in the full intervention area. To achieve such goal the removal of $55627 \mathrm{~m}^{3}$ was required. Numerical results (spatial and temporal variation of suspended solids and toxic concentrations) have been used to estimate the environmental risk of dredging operations (Gómez et al., 2014). 


\section{a) Suspended Solids Evolution}
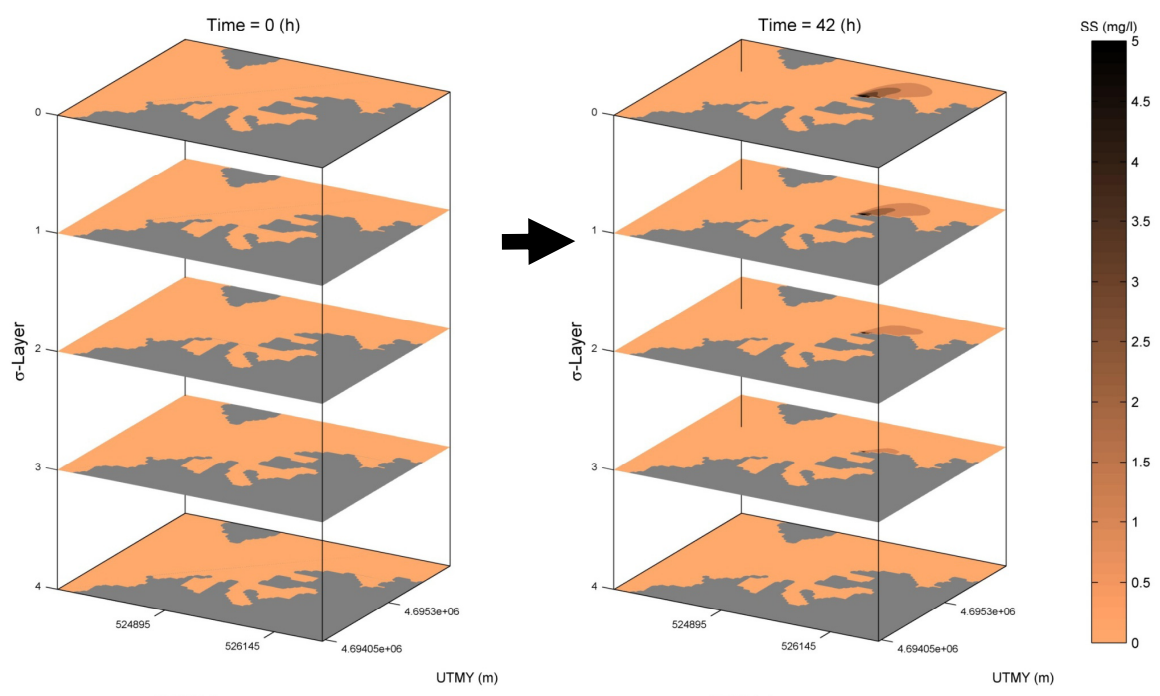

$\operatorname{UTMX}(\mathrm{m})$

UTMX (m)

b) Cadmium Evolution
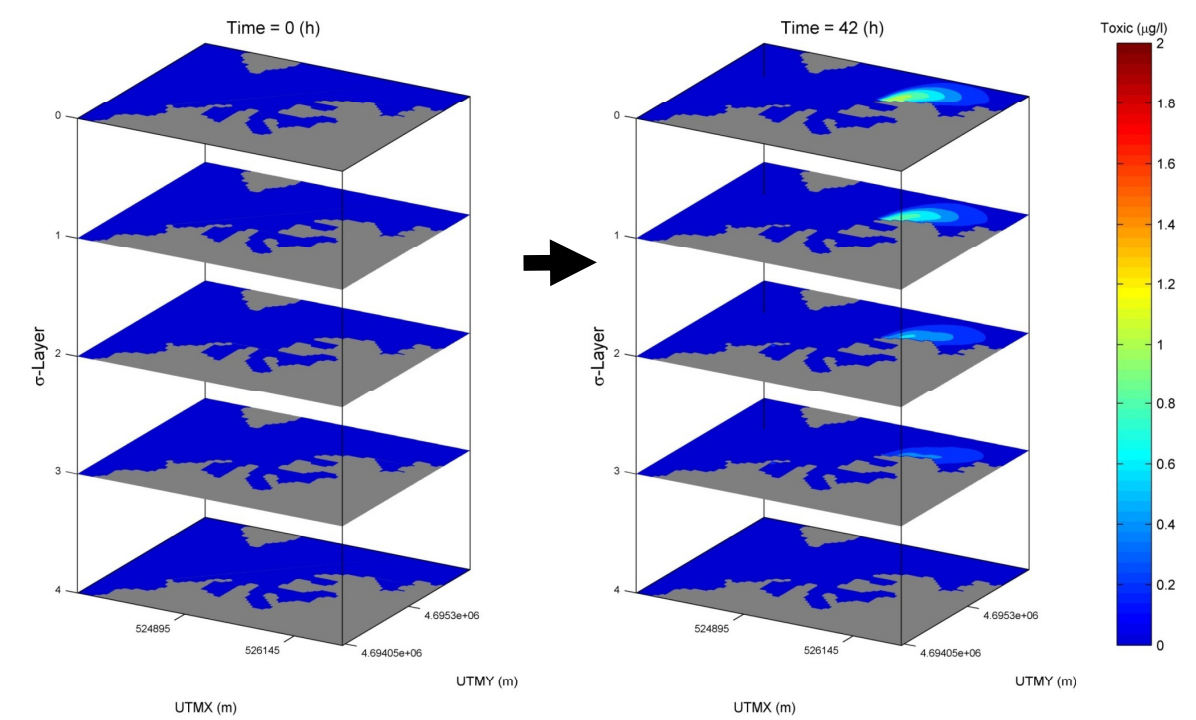

c) Dredging Bottom Evolution

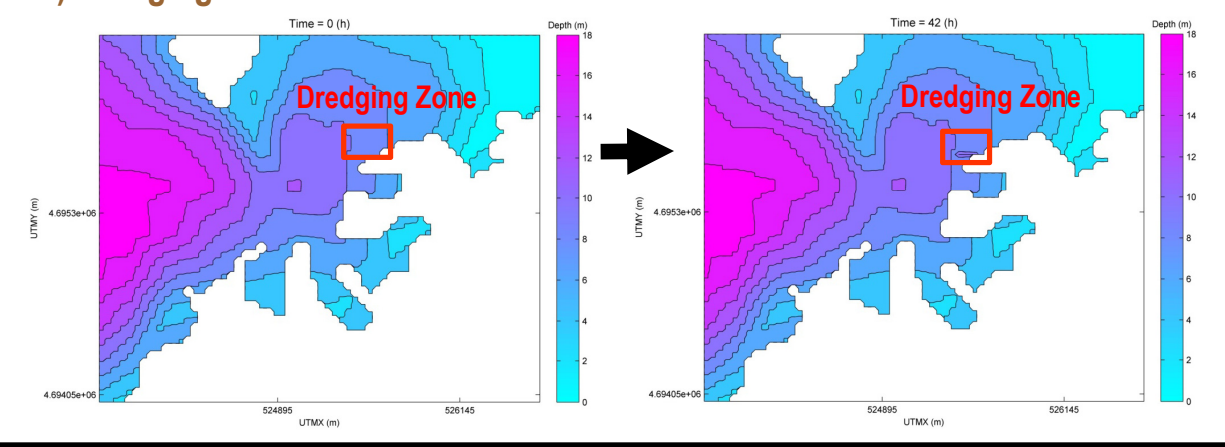

Fig. 3. (a) Suspension solids evolution during dredging process. (b) Cadmium concentration evolution during dredging process. (c) Depth evolution in the study area during dredging process. 


\section{Conclusions}

The IH-Dredge model advances the understanding of the selected dredging processes. Calibration and validation of the model were successfully carried out at the IHLab-Hydro at IH Cantabria. We have shown that the results from the numerical model (spatial and temporal variation of suspended solids and toxic concentrations) can be used to estimate the environmental risks associated with dredging operations. IHDredge has been applied to a real dredging operation conducted at the Port of Marin in the NorthernWest coast of Spain.

Acknowledgements. Part of this study has been sponsored by the INNPACTO programme (2008-2011) of the Spanish Ministry of Science and Innovation (IPT-310000-2100-17). The authors would like to thank the Marin Port Authority for the provided data.

\section{References}

Alvera-Azcárate, A., Ferreira, J., and Nunes, J.: Modelling eutrophication in mesotidal and macrotidal estuaries. The role of intertidal seaweeds, Estuar. Coast. Shelf Sci., 56, 1-10, 2003.

Bai, Y., Wang, Z., and Shen, H.: Three-dimensional modelling of sediment transport and the effects of dredging in the Haihe Estuary, Estuar. Coast. Shelf Sci., 56, 175-186, 2003.

Cancino, L. and Neves, R.: Hydrodynamic and sediment suspension modelling in estuarine systems. PartI: Description of the numerical models, J. Mar. Syst., 22, 105-116, 1999.

Cappucci, S., Amos, C., Hosoe, T., and Umgiesser, G.: SLIM: a numerical model to evaluate the factors controlling the evolution of intertidal mudflats in Venice Lagoon, Italy, J. Mar. Syst., 51, 257-280, 2004

de Boer, W.: Seagrass-sediment interactions, positive feedbacks and critical thresholds for occurrence: a review, Hydrobiologia, 591, $5-24,2007$.

Deltares: Delft3D users manual, Tech. rep., Deltares, the Netherlands, 1999.
Gómez, A. G., García Alba, J., Puente, A., and Juanes, J. A.: Environmental Risk Assessment of dredging processes - application to Marin harbour (NW Spain), Adv. Geosci., in press, 2014.

Hervouet, J. and Bates, P.: The TELEMAC modeling system, Hydrolog. Process., 14, 2209-2210, 2000.

Huang, J., Hilldale, R., and Greimann, B.: Erosion and Sedimentation Manual. Chapter 4: Cohesive Sediment Transport, Sedimentation and River Hydraulics Group, U.S. Department of the Interior, 2006

Jacobsen, F. and Rasmussen, E. B.: MIKE 3 MT: A 3-dimensional mud transport model, Technical rep. DG-12 to the commission of the european communities, Danish Hydraulic Institute, Hørsholm, Denmark, 1997.

Lumborg, U. and Pejrup, M.: Modelling of cohesive sediment transport in a tidal lagoon - an annual budget, Mar. Geol., 218, 1-16, 2005.

Nash, J. and Sutfliffe, J.: River flow forecasting through conceptual models part I - A discussion of principles, J. Hydrol., 10, 282 290, 1970.

Song, Y. T. and Haidvogel, D.: A semi-implicit primitive equation ocean circulation model using a generalized topography following coordinate system, J. Comput. Phys., 115, 228-244, 1994.

Vidal, J., Tejedor, B., Álvarez, O., and Martón, P.: Determinación experimental de los parámetros de erosión-depositación y su aplicación a un caso real: el canal de marea de Sancti Petri, Ciencias Marinas, Universidad Autónoma de Baja California, 31, 577-584, 2005.

Vlasbom, W.: Design of Dredging Equipment, Delft University of Technology, 2005.

Wu, Y. and Falconer, R.: A mass conservative 3D numerical model for predicting solute fluxes in estuarine waters, Adv. Water Res., 23, 531-543, 2000.

Wu, Y., Falconer, R., and Lin, B.: Modelling trace metal concentration distributions in estuarine waters, Ecol. Modell., 64, 699709, 2005.

Zheng, L., Chen, C., and Zhang, F.: Development of water quality model in the Satilla River Estuary, Georgia, Ecol. Modell., 178, 457-482, 2004. 